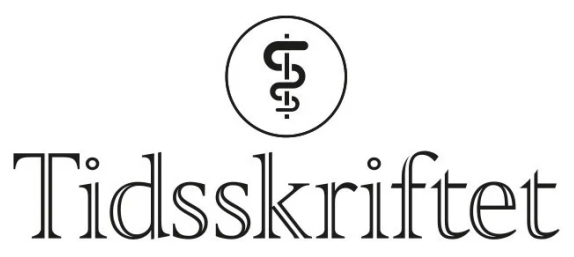

DEN NORSKE LEGEFORENING

\title{
Markedsføring av kosmetiske inngrep - en kvalitativ analyse
}

ORIGINALARTIKKEL

\section{VENKE FREDERIKE JOHANSEN}

venke.f.johansen@uia.no

Institutt for psykososial helse

Universitetet i Agder

Hun har ledet datainnsamling, litteratursøk og utarbeidelse av manuskriptet og bidratt med analyse og tolkning av data.

Venke Frederike Johansen er dr.philos. og førsteamanuensis emerita.

Forfatteren har fylt ut ICMJE-skjemaet og oppgir ingen interessekonflikter.

\section{THERESE ANDREWS}

Nordlandsforskning

Hun har bidratt med analyse og tolkning av data, litteratursøk og utarbeiding av manus.

Therese Andrews er dr.polit. i sosiologi og forsker 1.

Forfatteren har fylt ut ICMJE-skjemaet og oppgir ingen interessekonflikter.

\section{BAKGRUNN}

Markedsføring av kosmetiske inngrep er et tema som er lite studert i norsk kontekst, selv om problematiske sider ved slik markedsføring har vært pekt på i flere sammenhenger. I denne studien rettes oppmerksomheten mot hvordan tilbydere av kosmetiske inngrep markedsfører sine tjenester, hvem de henvender seg til og på hvilken måte.

\section{MATERIALE OG METODE}

Kritisk diskursanalyse ble brukt som ramme for en kvalitativ granskning av markedsføringen til 36 private klinikker. Datamaterialet er hentet fra Internett og aviser og består av tekst, stillbilder og videoklipp.

\section{RESULTATER OG FORTOLKNING}

I artikkelen løftes følgende markedsføringsstrategier frem: Tilbyderne omtaler kunden som pasient, alminneliggjør inngrep, retter oppmerksomheten mot kroppslige feil, spiller på femininitet og sensualitet, definerer naturlig utseende, lover bedre selvbilde og livskvalitet og tilbyr pakkeløsninger og finansieringsordninger. Underliggende budskap og mønstre som trer frem i de aktuelle strategiene, fortolkes i lys av teorier om kropp og kjønn, natur og kultur. 
De siste tiårene har det vært betydelig vekst i antall kosmetiske inngrep i Norge så vel som i andre vestlige land. Betegnelsen kosmetiske inngrep refererer til plastisk kirurgi og inngrep i hud og underhud (såkalte light-behandlinger), hvor kosmetiske hensyn er den avgjørende indikasjonen. En oversikt fra American Society of Plastic Surgeons (ASPS) viser at antall kosmetiske inngrep i USA økte fra rundt 6,7 millioner i 2000 til rundt18,1 millioner i 2019. Kvinner utgjorde over 9o \% av kundegruppen (11). I Norge er ikke omfanget og utviklingen over tid offisielt tallfestet, men en ledende markedsaktør opplyser for eksempel at de på ett

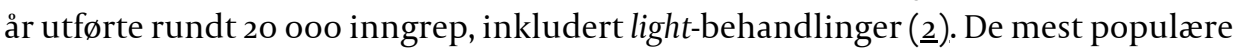
inngrepene innen plastisk kirurgi er brystforstørrelse og -løft, fettsuging, neseoperasjon og bukplastikk (3).

Flere har kritisert markedsføringen av kosmetiske inngrep. Den amerikanske plastikkirurgen Eric Swanson hevder at denne typen kirurgi er sterkt i strid med den medisinske tradisjonen, blant annet fordi kundene har bestemt seg for behandling før de kommer til konsultasjon (4). I tillegg brukes salgskonsulenter fremfor medisinsk personell, og det loves ofte fantastiske resultater samtidig som risikoen nedtones. Rufai og Davis finner tilsvarende tendenser (5). De har gransket websider til engelske klinikker og finner at klinikkenes salgsteknikker bryter med det britiske helsedepartementets retningslinjer. Taylor ser i sin studie en tydelig sammenheng mellom markedsføring av inngrep og kvinners egen legitimering av inngrep ( $\underline{6})$.

Denne typen virksomhet er lite studert i en norsk kontekst. Det finnes imidlertid et strengt lovverk, en forskrift fra 2005, som regulerer virksomheten (7.). Formålet med forskriften er å bidra til at markedsføringen skjer på en forsvarlig, nøktern og saklig måte. Det er ikke tillatt å henvise til andre kilder som har brukt markedsføring i strid med regelverket. For å forhindre forestillinger om at et bestemt kroppslig utseende er å foretrekke, er det heller ikke tillatt å henvende seg på måter som kan virke krenkende eller som spiller på folks lyter eller fordommer mot normale kroppsvariasjoner, for eksempel ved å bruke verdiladede uttrykk som «ridebukselår» eller «bulldogkinn». Pre- og postoperative bilder er ikke tillatt. Det samme gjelder bilder som kan virke krenkende eller spille på lyter. Å diskriminere mellom kjønn eller å nedtone risiko ved inngrepet er heller ikke tillatt.

Videre sier forskriften at markedsføring av kosmetiske inngrep ikke kan inneholde tilbud om kreditt, forbrukslån eller prisreduksjon dersom flere inngrep velges samtidig. Det skal gå klart frem hvem som er medisinsk ansvarlig i virksomheten, og det skal gis saklig og utfyllende informasjon. Når en mulig kunde henvender seg til tilbyderen, inntrer informasjonsplikten etter lov om helsepersonell § 10, og ved omtale av ulike inngrep må opplysninger reflektere medisinsk forsvarlige metoder etter $\S 13(\underline{8})$.

Selv om regelverket er strengt, er det likevel uklart hvor grensen går mellom markedsføring og informasjon (9.). I denne studien har vi undersøkt hvordan kosmetiske inngrep tilbys og hvilke underliggende budskap som trer frem gjennom ulike strategier. Vi retter oppmerksomheten bare mot tilbud til kvinner, som utgjør den største kundegruppen (1).

\section{Materiale og metode}

Artikkelen er basert på en kvalitativ innholdsanalyse av tekst og bildemateriale fra 36 private klinikker som utfører kosmetisk kirurgi. Da studien startet, fantes 68 slike klinikker ifølge HelseSmart.no (3). I tillegg kommer enkeltmannsforetak som tilbyr kosmetisk kirurgi og/eller light-behandlinger som leppeforstørrelse og botoxbehandling. I utvalget inngår både store, kjente klinikker og små klinikker, men ikke dem som kun tilbyr 
light-behandlinger. Klinikker i utvalget ble enten søkt opp direkte eller sporet via HelseSmart.no. Data er samlet inn over ett kalenderår fra og med januar 2018, med oppdatering i januar og november 2020.

Datamaterialet består av tekst, bilder og videofilmer fra de 36 klinikkene. Vi har rettet oppmerksomheten mot de vanligste kosmetiske inngrepene, som er brystforstørrelse, brystløft, fettsuging, neseoperasjon og bukplastikk, men også mot rumpeforstørring og kombinasjonsbehandlinger, som er gjenstand for økende etterspørsel. Noe av datamaterialet er hentet fra aviser, men det meste er fra klinikkenes hjemmesider på Internett med tilhørende lenker, blant annet til kundeuttalelser. Markedsføringsstrategier er ofte dynamiske, der tekst og bilder endrer seg over tid, men uttrykksformen har vært stabil i den perioden som datainnsamlingen har pågått.

Omfanget av datamaterialet har vært relativt stort. For eksempel beskriver klinikker brystforstørring med silikon med tekst på 5-10 sider, avhengig av layout. I tillegg kommer lenker til pasientuttalelser og utstyrsleverandører. Bilder av opererte bryster varierer fra o til 20, men vanligvis benytter hver klinikk minst ett illustrasjonsbilde. Noen klinikker presenterer i tillegg animasjonsvideoer av brystforstørrelse, informasjonsvideoer med fagpersonale og videofilmer med pasientuttalelser. I analysen ble oppmerksomheten rettet mot hvordan tilbydere presenterer seg selv og sine tjenester, hvem de henvender seg til og på hvilke måter.

Hvert enkelt element eller aspekt ble sortert etter kategori og deretter gruppert og regruppert i flere runder. Underliggende budskap og mønstre har blitt tolket basert på bruk av layout, farger, bilder, overskrifter, språk, begreper og videoklipp. Vi har også sett på helheten og identifisert både fellestrekk og særtrekk. I denne gjennomgangen har vi dradd

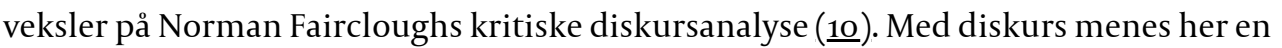
bestemt måte å uttrykke seg på som reflekterer en bestemt måte å tenke om emnet. Uttrykksrepertoaret omfatter et utvidet tekstbegrep, som ikke bare består av skrevet tekst, men også av bilder, videofilmer og layout.

Med kritisk diskursanalyse menes en detaljert metode for å analysere tekstene i lys av et kritisk perspektiv på teksters sosiale funksjon. Tilnærmingen har vært brukt i analyser innenfor en rekke forskningsfelt, for eksempel av Benestad (1ㅡ) og Johansen og medforfattere (12). Fairclough retter oppmerksomheten mot fenomenet som er gjenstand for granskning, mot hvordan bestemte gruppers interesser kommer til syne, og mot hvordan diskurser bidrar til å skape og/eller opprettholde ubalanse i maktforhold mellom grupper. Språk i bruk er, ifølge Fairclough, aldri nøytralt, men uttrykker et bestemt perspektiv på verden enten det er snakk om ordvalg eller bilder. Diskurser er både konstruerende og konstruerte, det vil si at de påvirker oppfatninger og praksiser samtidig som diskursen selv er påvirket av etablerte oppfatninger og praksiser.

Datamaterialet inneholder ingen personopplysninger.

\section{Resultater}

Nedenfor viser vi sju forskjellige strategier som klinikkene, i varierende grad, bruker i sin markedsføring. Strategienes underliggende budskap og mønstre poengteres og illustreres med sitater eller beskrivelser av bilder, fargebruk eller layout.

\section{OMTALER KUNDEN SOM PASIENT}

En gjennomgående strategi fra tilbydernes side er å omtale og tiltale kundene som pasienter. I eksempelet nedenfor antydes at man får bedre behandling som pasient enn som kunde:

«Etter hvert som bransjen dessverre har blitt mer og mer kommersiell, kan salgsaspektet komme til å bli viktigere enn det medisinske. (...) Derfor bør du alltid spørre deg selv: Føler jeg meg som en pasient eller føler jeg meg som en kunde? I første tilfelle vil dine interesser 
trolig være bedre ivaretatt enn i det andre.»

Å vektlegge pasientrollen fremfor kunderollen kan bidra til at inngrepene oppfattes som medisinsk helsehjelp. Dette forsterkes ved at tilbyderen gir inntrykk av at den opptrer som behandler og omsorgsyter og med det tar oppmerksomheten bort fra salgsaspektet. På samtlige websider brukes dessuten ord som trygghet, dyktighet og erfaring. Teksten er ofte illustrert med bilder av personalet, for eksempel i arbeid på operasjonssalen eller i samtale med pasienten. Bildene gir inntrykk av fornøyde, tillitsfulle pasienter.

\section{ALMINNELIGGJøR INNGREP}

De fleste tilbyderne uttrykker at kosmetiske inngrep er blitt svært vanlig. Noen legger også vekt på at det har blitt overkommelige priser for folk flest, og at den kosmetiske kirurgien i Norge holdes innenfor fornuftige rammer. Alminneliggjøring kommer også til uttrykk i omtalen av de enkelte inngrepene, særlig når det gjelder brystforstørrelse. For eksempel skriver en tilbyder at «vi opererer mange hundre pasienter hvert år». Andre eksempler gjelder neseoperasjoner: «Kosmetisk neseoperasjon (populært kalt nose-job) har i dag blitt et vanlig inngrep innen plastisk kirurgi.»

Motetrender kan bidra til at nye typer inngrep blir etterspurt for deretter å bli tilbudt av stadig flere klinikker. Et eksempel er «Brazilian butt lift» (rumpeforstørring med eget fett), som for få år siden ikke var et tilbud i Norge, blant annet på grunn av komplikasjoner (13). Nå finnes ti klinikker som tilbyr dette (hvorav åtte inngår i studien). En klinikk skriver:

«Å ha en fyldig og spenstig rumpe blir av mange sett på som både attraktivt og ungdommelig. Å få rumpen forstørret eller løftet kirurgisk var tradisjonelt mest etterspurt i Sør-Amerika og særlig Brasil, derav kalles et slikt inngrep gjerne for Brazilian butt lift» (BBL). Trenden har for lengst spredt seg til vesten og er nå blitt en av de operasjonene som $\emptyset$ ker mest i etterspørsel.»

Et paradoks til alminneliggjøringen er at mange tilbydere legger vekt på diskresjon og gjør oppmerksom på at de holder til i anonyme lokaler og kan tilby diskré innganger.

RETTER OPPMERKSOMHETEN MOT KROPPSLIGE FEIL

Formuleringer som innbyr til misnøye med egen kropp er utbredt, selv om budskapet som regel er subtilt. Et eksempel på dette er markedsføring av brystforstørrelse, hvor en tilbyder skriver: «For mange kvinner er brystene en viktig del av ens personlighet og selvfølelse». En annen tilbyder formulerer følgende: «Ved brystforstørring med silikonimplantat kan små og tomme bryst få normal størrelse og form.» Det psykiske aspektet trekkes også inn, som for eksempel: «For kvinner kan det være en påkjenning å være misfornøyd med brystene, derfor er det mange som oppsøker oss for spørsmål og informasjon.»

En subtil oppfordring til å se på seg selv med et kritisk blikk gjelder også ansiktet, blant annet nesen, hvor en tilbyder skriver: «En harmonisk nese 'blir ikke lagt merke til'. En nese som derimot ikke harmonerer med ansiktet på grunn av sin størrelse eller avvikende form vil tiltrekke seg oppmerksomheten.» I påfølgende liste går det frem hva som vil tiltrekke seg oppmerksomhet, underforstått på en negativ måte: store nesebor, bred nese, høy neserygg, stor krumning på nesen eller nese som tipper.

Flere tilbydere uttrykker seg også negativt om spor av aldring, med overskrifter som: «skru klokken ti år tilbake». Negative aldringstegn utdypes i teksten: «Sliter du med slapp hud, dype rynker, trette øyne eller synkende kinn? Da kan et ansiktsløft være løsningen for deg.» I omtalen fremstilles aldringstegn som noe utiltalende som kan være vanskelig å leve med, særlig for kvinner.

Noen klinikker uttrykker at noe ved kroppen (for eksempel små, tomme bryster eller en spesiell form på nesen m.m.) kan være «kosmetisk og sosialt skjemmende». Enkelte bruker ulike betegnelser om aldringstegn og variasjoner i utseende som for eksempel: sinnarynke, grevinnearmer, sur munn, hamsterposer, gummy-smile, ridebukselår, bulldogkinn og/eller kalkunhals. Ordet såkalt foran selve betegnelsen går igjen og kan være brukt for å legitimere begrepsbruken. Videre finnes ofte en indirekte oppfordring om å granske egen kropp, for 
eksempel egen rumpe, med påfølgende antydninger om at operasjon kan være løsningen: «(...) hvis rumpeballene er altfor flate eller kvadratformete slik at man ønsker at denne kroppsdelen blir bedre formet og rund.»

En av klinikkene oppsummerer sine tjenester i én setning: «La deg inspirere av våre tilbud.» Underforstått: Her vil alle finne noe ved egen kropp som bør rettes på.

\section{SPILLER PÅ FEMININITET OG SENSUALITET}

Spill på femininitet og sensualitet både i tekst, bilder og layout kommer til uttrykk blant annet på følgende måte: «En brystforstørrelse kan hjelpe deg til å få den kvinnelige figuren du alltid har ønsket deg (...)» eller: «(...) Brystene mister sin naturlige fasong og fasthet og begynner å synke. Dette kan gi kvinnen en følelse av mangel på feminitet, som kan resultere i nedsatt selvtillit og sjenanse, noe som påvirker det sosiale livet.»

I noen tilfeller vises bilder av opererte bryster, noen ganger delvis dekket av hender, andre i sexy undertøy. Bildene ser ut til å være manipulert i form av myke konturer og duse farger eller svart/hvitt-sjatteringer. På en webside kan man klikke seg inn på et «brystgalleri» med 15 nærbilder av bryster ledsaget av teksten «(...) slik at du som vurderer en brystoperasjon, kan se og kanskje finne den størrelsen på bryster du selv ønsker». Bildeserien ender i et konsultasjonsskjema. Også når det gjelder rumpeforstørring, indikerer både tekst og bilder (av for eksempel bikinikledde rumper med sand på) hva som kan være sexy og feminint.

Andre typer inngrep som gir løfter om $ø \mathrm{kt}$ femininitet og sensualitet, er leppeforstørrelse, hvor enkelte tilbydere skriver at «mange kvinner drømmer om fyldige og myke lepper (...)».Videre blir neser definert som enten feminine eller maskuline, som dette eksempelet viser: «Det er ofte et ønske at nesen skal bli mindre dominerende og dels mer feminin eller mindre maskulin.»

Det benyttes dessuten layout med lenker til uttalelser fra personer som har fătt utført inngrep, som handler om forhold som tilbydere ikke kan si noe om dersom de følger forskriften, for eksempel uttalelser om komplekser på grunn av små bryster. En kvinne som hadde fått utført brystløft og brystforstørring, forteller at hennes fem år gamle datter uttrykte at det var et mirakel da hun fikk se de nye brystene til moren.

\section{DEFINERER NATURLIG UTSEENDE}

Samtlige tilbydere legger vekt på det naturlige resultatet, for eksempel denne:

«Enten du vil forbedre det du har eller gjenopprette det som var, er målet det samme: å følge det skandinaviske naturlige skjønnhetsidealet med naturlige attraktive proporsjoner og riktig balanse; En brystforstørrelse vil gi deg naturlige og vakre bryster.»

Eksempler på at kirurgen leverer et naturlig resultat, kommer også til uttrykk i dette sitatet: «(...) Dr. [navn] legger stor vekt på at resultatet skal være naturlig.» Det er imidlertid ofte en disharmoni mellom tekst og bilder, hvor teksten understreker at kirurgen vektlegger et naturlig utseende, mens bildene viser det motsatte. Bilder av bryster, midje, rumpe, lepper eller ansikt er ofte uforenlige med et naturlig utseende, men ved å bruke begreper som naturlig skjønnhet og lignende kan tilbydere skape forestillinger om hva som er naturlig vakkert.

\section{LOVER BEDRE SELVBILDE OG LIVSKVALITET}

Antydning om gevinster utover det som selve produktet kan inneholde, kommer for eksempel til uttrykk på følgende måte:

«Målet med kosmetisk kirurgi og estetiske behandlinger skal ikke være å forandre deg til noen andre. Derimot kan vi forbedre eller gjenopprette utseendet, eller bare korrigere noe som du selv synes er plagsomt. Dette kan i sin tur bidra til økt livskvalitet.»

Muligheter for å bli kvitt psykiske problemer, antydes også: «Hvis det brukes med rett hensikt blir en plastikkoperasjon på ansiktet eller kroppen en positiv opplevelse, og du kan også bli kvitt fysiske, sosiale og/eller psykiske ubehag.» Noen markedsfører tjenestene sine ved å fortelle at tidligere pasienter har fått økt livskvalitet, som denne: «Bukplastikk er en 
av de vanligste operasjonene ved vår klinikk og har gitt mange pasienter ny livskvalitet.» Løfter om konkrete effekter som går utover det enkelte produktet eller den enkelte tjenesten, er ikke uvanlig, som for eksempel denne: «Vi er opptatt av å gi deg bedre livskvalitet - uansett grunn.»

\section{TILBYR PAKKELØSNING OG FINANSIERINGSORDNINGER}

I tilbudene finnes også argumenter for raskere og bedre resultat, færre operasjoner og færre dager borte fra arbeid dersom det gjennomføres flere inngrep under ett. Dette kan forstås som "pakketilbud», selv om prisreduksjon ikke er eksplisitt nevnt. Noen pakkeløsninger går under betegnelsen Mommy Makeover, som er et tilbud om flere operasjoner i ett. Annonseteksten antyder at fødselen kan ha satt spor - underforstått ikke-attraktive spor som kan korrigeres ved hjelp av ulike inngrep. Aktuelle kombinasjoner kan være «mageplastikk kombinert med brystforstørring, intimkirurgi kombinert med brystforstørring, mageplastikk kombinert med figurforming» eller seks andre kombinasjoner som involverer kroppsdeler som kan ha blitt påvirket (negativt) under svangerskap og fødsel. Enkelte antyder at kombinasjonsbehandlinger kan bli billigere: "Verdt å merke seg at ved denne type kombinasjonsinngrep får pasienten opptil $15 \%$ rabatt på tilleggsoperasjon og $50 \%$ rabatt ved figurforming.»

Også når det gjelder ansiktsoperasjoner tilbys kombinasjonsløsninger: «Ved å utføre flere inngrep i samme sesjon, unngår du flere fraværsperioder. Du vil i tillegg unngå flere perioder med ubehag fra inngrepene.» I en lokalavis annonserer en klinikk med jevne mellomrom med $50 \%$ prisavslag på mimikkrynkebehandling ved innmelding $\mathrm{i}$ kundeklubben. Enkelte klinikker har også høsttilbud til halv pris.

Noen tilbyr finansieringsordninger, hvor de skriver at privatøkonomien ikke skal være til hinder for større inngrep, eller at de har tilbud på større inngrep, for eksempel brystforstørring, dersom kunden bestemmer seg innen en gitt dato.

\section{Diskusjon}

Studien avdekker flere underliggende budskap. Et gjennomgående signal er at kvinnekroppen er et objekt som kan og bør modelleres i tråd med kulturelle (og stereotype) forståelser av hvordan en slik kropp bør eller skal se ut. Dette tydeliggjøres også via beskrivelser av hvordan kroppen ikke bør se ut, for eksempel at tomme bryster eller en spesiell neseform kan være sosialt skjemmende, at en rumpe er for kvadratisk, eller at fødselen har satt spor.

Forestillinger om det ideelle utseende, inkludert hva som er feminint og sexy, ser langt på vei ut til å formes i selve forandringsrommet - av tilbyderne: Kvinner bør skjule spor av levd liv (som alder og fødsler), og naturlige kroppsvariasjoner er lite attraktive og en byrde for kvinner. Samtlige tilbydere bruker uttrykket naturlig resultat, og med dette formes et inntrykk av at forstørrede bryster eller rumpe, endrede neser og glatt hud speiler det naturlige. Bilder av opererte kroppsdeler overgår ofte naturen selv og er sjelden forenlige med en levd kropp.

Et ytterligere uttrykk for objektivering er at flere av bildene som presenteres, synes å være tatt med det Mulvey kaller det mannlige blikket (the male gaze), det som betrakter kvinner som seksualobjekt (14). Franklin, Lury og Stacey hevder at natur og kultur er to sider ved kroppen som etterligner hverandre, med den forskjell at man velger kulturen fremfor naturen, her: det opererte (15). Kulturen stiller krav til naturen, hvor det nye «naturlige utseendet» overskrider det naturlige. Kroppsindustrien legger dermed et konstant press på jenter og kvinner hva angår utseendet, slik at særlig de mest sårbare kontinuerlig gransker

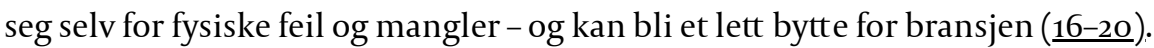

En annen strategi som trer frem, er å kle kosmetisk kirurgi i «sykdomsdrakt», blant annet ved å bruke betegnelsen pasient fremfor kunde. Ifølge helsepersonelloven (므) er en pasient en person som henvender seg til helse- og omsorgstjenesten for helsehjelp, eller en som 
helse- og omsorgstjenesten tilbyr helsehjelp. Det gir pasientstatusen en tilhørighet innenfor det medisinske ansvarsområdet og befester samtidig en skjevhet i maktrelasjonen, der pasienten står i en underlegen posisjon.

Om det friske kles i en sykdomsdrakt eller medikaliseres, og informasjonen glir over i ren markedsføring, kan dette være vanskelig for kunden å oppdage. Innholdsmarkedsføringen har da en form som ligner redaksjonell journalistikk. Informasjon om inngrepene (herunder hva som kan fikses på) via bilder av kroppsdeler og lett tilgjengelige konsultasjonsskjema kan oppfattes som en oppfordring til å fikse på egen kropp. Når websidene likner på redaksjonell journalistikk, kan salgsmotivet bli vanskelig å oppdage. I tillegg preges overskriftene av positivt ladede ord som gjentas hyppig, blant annet trygghet, sikkerhet, garanti, dyktighet, kompetanse og erfaring. Bilder, som er et sentralt virkemiddel i

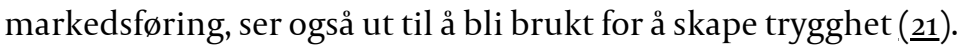

Studien viser altså at tilbydere av kosmetisk kirurgi henvender seg til mulige kunder ved å antyde at visse kroppsdelers karakter kan være en påkjenning og bidra til lav selvfølelse, svekket sensualitet og dårlig livskvalitet og at dette kan rettes opp og forbedres ved ulike inngrep. Det som skrives før omtale av selve varen og $ø$ ør presentasjonen av et konkret tilbud, er viktig for å overbevise kunden. Innenfor markedsføringsteori kalles dette presuation (før-overbevisning), og den påfølgende reklamen for inngrepet kan derfor oppfattes som et tilbud om hjelp i stedet for som et salgsfremstøt (22).

Datamaterialet tyder på at klinikkene kjenner til offisielle krav. De viser for eksempel ikke før- og etterbilder, de informerer om medisinsk kompetanse og om hvordan inngrep gjennomføres. Samtidig fremstilles ulike inngrep som alminnelige, det spilles på lyter og fordommer mot normale kroppsvariasjoner, og det loves gevinster på flere plan både via tekst og bilder. Finansielle fordeler tilbys også. Det er en hårfin balanse mellom informasjon og markedsføring, som lett kan tippe over i ren markedsføring. Om strategiene er i strid med lovverket, bør imidlertid granskes juridisk i en egen studie.

I denne studien er markedsføringsstrategier analysert fra vårt faglige ståsted. Slike strategier kan imidlertid studeres på andre måter og ved bruk av andre teoretiske perspektiver for å utvide kunnskapen om dette forskningsfeltet. Et vesentlig aspekt som ikke er berørt i denne studien, er hvilke erfaringer kvinner som har fått utført kosmetisk kirurgi, har gjort seg rundt markedsføring sett opp mot det produktet de har fått. Dette er det viktig å undersøke i en egen studie.

Artikkelen er fagfellevurdert.

\section{LITTERATUR}

1. Plastic SSR. American Society of Plastic Surgeons, 2019.https://www.plasticsurgery.org/documents/News/Statistics/2019/plastic-surgery-statistics-fullreport-2019.pdf Lest 9.3.2021.

2. Sti TK. Skjønnhetsbransjen er i eksplosiv vekst: - I Norge er det helt bananas. ABCnyheter/Finansavisen 16.6.2018. https://www.abcnyheter.no/helse-oglivsstil/helse/2018/o6/24/195408313/skjonnhetsbransjen-er-i-eksplosiv-vekst-i-norge-er-det-heltbananas Lest 15.9.2020.

3. Austad G. Plastisk kirurgi. HelseSmart.no. https://www.helsesmart.no/behandling/plastiskkirurgi\#Operasjon Lest 19.9.2020.

4. Swanson E. The commercialization of plastic surgery. Aesthet Surg J 2013; 33: 1065-8. [PubMed] [CrossRef]

5. Rufai SR, Davis CR. Aesthetic surgery and Google: ubiquitous, unregulated and enticing websites for patients considering cosmetic surgery. J Plast Reconstr Aesthet Surg 2014; 67: 640-3. [PubMed] [CrossRef]

6. Taylor JS. Buying and selling breasts: cosmetic surgery, beauty treatments and risk. Sociol Rev 2012; 6o: 635-53. [CrossRef] 
7. FOR-2005-07-01-749. Forskrift om markedsføring av kosmetiske inngrep. https://lovdata.no/dokument/SF/forskrift/2005-07-01-749 Lest 9.3.2021.

8. LOV-1999-07-02-64. Lov om helsepersonell m.v. https://lovdata.no/dokument/NL/lov/1999-07-02-64 Lest 9.3.2021.

9. Thomassen KM. Lovlig informasjon om kosmetiske inngrep. Tidsskr Nor Lægeforen 2006; 126:3326. [PubMed]

10. Fairclough N. Media discourse. New York, NY: Oxford University Press, 1995.

11. Hågvar YB. Djevelen ligger i diskursen - En kritisk diskursanalyse av Marte Krogh-saken i VG Norsk medietidsskrift 2013; 20: 200-22.

12. Johansen VF, Andrews TM, Haukanes $\mathrm{H}$ et al. Symbols and meanings in breast cancer awareness campaigns. NORA 2013; 21:140-55. [CrossRef]

13. Eftestøl I, Hetland K. Lege advarer mot rumpe-fiksing. NRK Rogaland 18.8.2016. https://www.nrk.no/rogaland/lege-advarer-mot-rumpe-fiksing-1.13091953 Lest 9.3.2021.

14. Mulvey L. Visual pleasure and narrative cinema: I: Braudy L, Cohen M, red. Film theory and criticism: Introductory readings. New York, NY: Oxford University Press, 1999: 833-44.

15. Franklin S, Lury C, Stacey J. Global nature, global culture. London: SAGE Publication, 200.

16. Eckler P, Kalyango Y, Paasch E. Facebook use and negative body image among U.S. college women. Women Health 2017; 57: 249-67. [PubMed][CrossRef]

17. Mogstad KL. Kroppsklemma. Hvordan være trygge og gode voksne for barn og unge i et kroppsfiksert samfunn. Oslo: Cappelen Damm, 2017.

18. Featherstone M. Body, image and affect in consumer culture. Body Soc 2010; 16: 193-221. [CrossRef]

19. Mendelson B. In your face: The hidden history of plastic surgery and why looks matter. Richmond: Hardie Grant Books, 2013.

20. Connell R. Gender: In world perspective. Cambridge: Polity Press, 2009.

21. Nisja-Wilhelmsen P. Praktisk innholdsmarkedsføring. Oslo: Gyldendal Akademisk, 2017.

22. Cialdini R. Fra påvirkning til overbevisning. Revolusjonerende nye metoder. Oslo: Abstrakt forlag, 2017 .

Publisert: 20. mai 2021. Tidsskr Nor Legeforen. DOI: 10.4045/tidsskr.20.0766

Mottatt 24.9.2020, første revisjon innsendt 12.12.2020, godkjent 6.4.2021.

Publisert under åpen tilgang CC BY-ND. Lastet ned fra tidsskriftet.no 26. april 2023. 